\title{
Clinical Outcomes and Independent Risk Factors for 90-day Mortality in Critically-ill Patients Infected With SARS CoV-2: a Multicenter Study in Turkish Intensive Care Units
}

Kursat Gundogan ( $\nabla$ kgundogan@erciyes.edu.tr )

Erciyes University, Turkey

Ismail Hakki Akbudak

Pamukkale Üniversitesi Tıp Fakültesi: Pamukkale Universitesi Tip Fakultesi

Pervin Hanci

Trakya Üniversitesi Tıp Fakültesi: Trakya Universitesi Tip Fakultesi

Burcin Halacli

Hacettepe University: Hacettepe Universitesi

Sahin Temel

Erciyes University: Erciyes Universitesi

Zuhal Gullu

Yenimahelle Educational and Training Hospital, Ankara

Kamil Inci

Yenimahelle Educational and Training Hospital, Ankara

Yeliz Bilir

Lutfi Kirdar Educational and training Hospital,Istanbul

Firdevs Tugba Bozkurt

Mehmet Akif Inan Educational and Training Hospital, Sanliurfa

Fatma Yildirim

Diskapi Educational and Training Hospital, Ankara

Meltem Simsek

Diskapi Educational and Training Hospital, Ankara

Recep Civan Yuksel

Kayseri, City Hospital

Esma Eren

Kayseri, City Hospital

Neriman Defne Altintas

Ankara University, Ankara

Leyla Talan

Ankara University' Ankara 
Gulseren Elay

Gaziantep University, Gaziantep

\section{Goksel Guven}

Tokat State Hospital, Tokat

Iskender Kara

Selcuk University, Konya

\section{Emre Aydin}

Dicle University, Diyarbakir

\section{Seda Yilmaz}

Health Science University, Kutahya

\section{Tugce Mengi}

Omer Halisdemir University, Nigde

\section{Sema Sari}

Omer Halisdemir University, Nigde

\section{Turkay Akbas}

Duzce University, Duzce

\section{Burcu Acar Cinleti}

Suat Seren Educational and Training Hospital, Izmir

\section{Nazire Ates Ayhan}

Cukurova University, Adana

\section{Deniz Aral Ozbek}

Hacettepe University

\section{Taha Koray Sahin}

Hacettepe University, Ankara

\section{Asli Acikgoz}

Selcuk University, Konya

\section{Ali Umit Esbah}

Duzce University

\section{Ahmet Firat}

Cukurova University, Adana

\section{Ferhan Aydemir}

Dokuz Eylul University, Izmir

\section{Mehmet Cagatay Gurkok}

Dokuz Eylul Univrsity

\section{Avsar Zerman}

Ahi Evran University, Kirsehir

\section{Ayca Gumus}

Ahi Evran Univrsity, Kirsehir

\section{Melda Turkoglu}


Gazi University, Ankara

\section{Muge Aydogdu}

Gazi University, Ankara

\section{Ramazan Ulu}

Firat University, Elazig

\section{Jale Bengi Celik}

Selcuk University, Konya

\section{Canan Balci}

Health Science University, Kutahya

\section{Cenk Kirakli}

Suat Seren Educational and Training Hospital

\section{Emre Karakoc}

Cukurova University, Adana

\section{Ezgi Ozyilmaz}

Cukurova University, Adana

\section{Ebru Ortac Ersoy}

Hacettepe University, Ankara

\section{Serpil Ocal}

Ankara University, Ankara

\section{Irem Akin Sen}

Erzurum Educational and Training Hospital, Erzurum

\section{Ibrahim Hakki Tor}

Erzurum Educational and Training Hospital, Erzurum

\section{Bilgin Comert}

Dokuz Eylul University, Izmir

\section{Begum Ergan}

Dokuz Eylul University, Izmir

\section{Kemal Tolga Saracoglu}

Lutfi Kirdar Educational and Training Hospital, Istanbul

Julide Ergil

Diskapi Educational and Training Hospital, Ankara

\section{Ummu Gulsum Yuksel}

Tokat State Hospital, Tokat

\section{Nuri Tutar}

Erciyes University, Kayseri

\section{Murat Sungur}

Erciyes University, Kayseri

\section{Arzu Topeli}

Hacettepe Uiversity, Ankara 


\section{Research}

Keywords: COVID-19, critical care, prognosis, survival, mechanical ventilation

Posted Date: January 21st, 2021

DOl: https://doi.org/10.21203/rs.3.rs-150961/v1

License: (c) (i) This work is licensed under a Creative Commons Attribution 4.0 International License. Read Full License

Version of Record: A version of this preprint was published at Balkan Medical Journal on August 5th, 2021. See the published version at https://doi.org/10.5152/balkanmedj.2021.21188. 


\section{Abstract}

Background: There are limited data on long-term outcome and mortality predictors of COVID-19 from different parts of the world. The aim of this study was to determine risk factors of 90 -day mortality in critically-ill patients infected with SARS-CoV-2 in Turkish ICUs.

Methods: This multicenter, retrospective study was performed in 26 ICUs in Turkey. All patients with confirmed SARS-CoV2 infection, requiring more than 24 hours of ICU follow-up were included in the study. Demographics, clinical characteristics, laboratory variables, respiratory support, treatment types, and survival data were recorded.

Results: A total of 421 patients were included in the study. The median age was 67 (IQR: 57-76) years, and 251 patients (59.6\%) were men. 90-day mortality rate was $55.1 \%$. Factors independently associated with 90-day mortality were receiving invasive mechanical ventilation (HR 4.09 [95\% Cl: 2.20-7.63]), admission lactate level $>2 \mathrm{mmol} / \mathrm{L}$ (2.78 [1.93-4.01]), age $\geq 60$ years (2.45 [1.48-4.06)]), having cardiac arrhythmia during ICU stay (2.01 [1.27-3.20]), receiving vasopressor treatment (1.94 [1.32-2.84]), positive fluid balance of $\geq 600 \mathrm{ml} /$ per day during ICU follow-up (1.68 [1.21-2.34]), admission $\mathrm{PaO}_{2} / \mathrm{FiO}_{2}$ ratio of $\leq$ $150 \mathrm{mmHg}$ (1.66 [1.18-2.32], and baseline ECOG score $\geq 1$ (1.42 [1.00-2.02].

Conclusion: This study has shown that long-term mortality was high in critically-ill COVID-19 patients in Turkish ICUs. Invasive mechanical ventilation, high lactate level, older age, presence of cardiac arrhythmia, need for vasopressor treatment, positive fluid balance, severe hypoxemia and not having fully-active performance were related with mortality.

\section{Introduction}

Coronavirus disease-2019 (COVID-19) pandemic caused by severe acute respiratory syndromeCoronavirus-2 (SARS-CoV-2) is a global threat causing critical illness in $5-26.4 \%$ of the affected patients [1-5]. At the beginning of the pandemic, acute respiratory failure caused by severe pneumonia and acute respiratory distress syndrome (ARDS) was the predominant complication of COVID-19, whereas subsequently, it was realized that virus is damaging the vascular endothelium and causing multi-system inflammatory syndrome [6] and several complications such as kidney, cardiac, liver and brain injury [7, 8], vascular thrombosis $[9,10]$, and macrophage activation syndrome $[4,7,11]$. Short and long-term mortality of critically-ill COVID-19 patients are quite high. While intensive care unit (ICU), in-hospital, 28-day and 60day mortality rates were reported to be up to $62 \%[4,7,12-15]$, mortality was reported to be even higher in patients who were mechanically ventilated (35.7-100\%) [14, 16-18]. There is limited data about long term prognosis of COVID-19 patients. To the best of our knowledge, there is just one study reporting 90day mortality which was $31.0 \%$ [19]. Patient results may differ according to the geographical characteristics, income levels of countries, as well as surge capacity of ICUs. The aim of this study was to determine risk factors of 90-day mortality in patients with COVID-19 who were admitted to the Turkish ICUs. 


\section{Method}

This study was performed retrospectively in 26 intensive care units of 23 hospitals in Turkey between 11 March 2020-11 July 2020. Approvals from the Ministry of Health (2020-05-04T09_48_29) and Erciyes University Ethics Committee were obtained for the study (Date: 22.07 .2020 no:2020/401). Informed consent was waived.

\section{Data Collection}

Data were collected from the hospital electronic record systems and patient charts. Patients with laboratory confirmed COVID-19 and who had been followed in the ICUs with respiratory failure for more than 24 hours were included in the study. Laboratory confirmation for SARS-CoV-2 was defined as a positive result of Real Time Polymerase Chain Reaction assay of nasal, pharyngeal swabs or endotracheal aspirate according to WHO guideline [20] or positive result in antibody testing with typical thorax computed tomography findings according to the Radiological Society of North America Expert Consensus Statement [21] excluding other diagnosis.

The following variables at admission, for the first 10 days of ICU follow-up till discharge from the hospital were collected on electronic-case report forms as follows: age, gender, Eastern Cooperative Oncology Group Performance Status (ECOG) score, Acute Physiology and Chronic Health Evaluation II (APACHE-II) score, Sequential Organ Failure Assessment (SOFA) score, co-morbidities, admission place, symptoms, duration from symptom onset to hospital and ICU admission, partial arterial oxygen pressure $\left(\mathrm{PaO}_{2}\right)$ to fraction of inspired oxygen $\left(\mathrm{FiO}_{2}\right)$ ratio, lactate, neutrophil to lymphocyte ratio, D-dimer, respiratory support type (conventional $\mathrm{O}_{2}$, high flow nasal $\mathrm{O}_{2}$ (HFNO), non-invasive ventilation (NIV) and invasive ventilation (IMV)), types of treatment, neuromuscular blocker use, vasopressor treatment, mean fluid balance per day (mean value of intake minus output per day for 10 days follow-up period), acute kidney injury (AKI) as assessed by Kidney Disease: Improving Global Outcomes (KDIGO) score [22], development of delirium, new onset cardiac arrhythmia (including atrial fibrillation/flutter, sustained or non-sustained ventricular tachycardia), length of ICU and hospital stay, ICU, 28-day, hospital, 60 and 90-day mortality rates. For patients who were discharged from the hospital or transferred to another hospital prior to 90 days, national death notification system for mortality status was checked.

\section{Statistical analysis}

Data were analyzed using the PASW Statistics for Windows, version 18.0 (SPSS Inc., Chicago, IL, USA). Descriptive statistics were expressed as numbers and percentages (\%) for categorical variables and as median and interquartile range (IQR) for numerical variables. In two and multiple group comparisons of categorical variables, chi-square test or Fisher's exact test was used as appropriate. For numerical variables, in two group comparisons, t-test or Mann-Whitney $U$ test was used as appropriate. Multivariate Cox regression analysis was performed by stepwise backward likelihood ratio method using the variables 
to be related with the survival in the univariate analysis. Kaplan-Meier survival curves until day 90 were computed and were compared according to respiratory support using log-rank test. Statistical significance level was accepted as $p<0.05$.

\section{Results}

Patients were included from 26 ICUs (16-university hospital, 10-public hospital) in 23 hospitals (Table S1 and Figure S1). A total of 421 patients were enrolled in the study between 10 March 2020 and 10 June 2020. Of patients, 376 were PCR (+) and 45 were antibody (+) for COVID-19. Patients' 90-day mortality rate was $55.1 \%$ (Fig. 1).

Patient characteristics at admission and 90-day survivor, non-survivor group comparisons are seen in Table 1. The median age was 67 (57-76) years, 297 (70.5\%) patients being over 60 years old. Nonsurvivor patients were older than survivors $(p<0.001)$. Median values of the APACHE II score and SOFA score were 17 (12-26) and 5 (3-8), respectively. APACHE and SOFA scores of the non-survivor patients were higher than the survivors ( $p<0.001$ for both). Of patients, $87.6 \%$ had at least one co-morbidity. Hypertension (51.3\%) was the most common one, followed by diabetes (30.9\%) and cardiac diseases (25.2\%). The most common admission symptoms were shortness of breath $(63.7 \%)$, cough $(57.2 \%)$ and fever (55.1\%). Median time from symptom onset to hospital admission was $3(2-7)$ days and ICU admission was 7 (4-10) days. Median $\mathrm{PaO}_{2} / \mathrm{FiO}_{2}$ ratio was 140 (88.2-204.5) $\mathrm{mmHg}$ and was lower in non-survivors $(p<0.001)$. Blood lactate $(p<0.001)$, neutrophil / lymphocyte ratio $(p<0.001)$ and D-dimer levels were higher in the non-survivor group than the survivors $(p<0.01)$. 
Table 1

Patients' characteristics at admission

\begin{tabular}{|c|c|c|c|c|}
\hline & $\begin{array}{l}\text { All patients } \\
n=421\end{array}$ & $\begin{array}{l}\text { 90-day } \\
\text { Survivors } \\
n=189\end{array}$ & $\begin{array}{l}\text { 90-day } \\
\text { Non- } \\
\text { survivors } \\
\mathrm{n}=232\end{array}$ & $\begin{array}{l}\mathrm{P} \\
\text { value }\end{array}$ \\
\hline Age, yrs, median (IQR) & $67(57-76)$ & $58(49-69)$ & $72(64-79)$ & $<0.001$ \\
\hline Age $\geq 60$ yrs, $n(\%)$ & $297(70.5)$ & $89(47.1)$ & $208(89.7)$ & $<0.001$ \\
\hline Male gender, $n(\%)$ & $251(59.6)$ & $111(58.7)$ & $140(60.3)$ & 0.74 \\
\hline ECOG score*, n (\%) & & & & $<0.001$ \\
\hline 0 & $187(45.6)$ & $114(62.3)$ & $73(32.2)$ & \\
\hline 1 & $76(18.5)$ & $30(16.4)$ & $46(20.3)$ & \\
\hline 2 & $74(18.0)$ & $24(13.1)$ & $50(22.0)$ & \\
\hline 3 & $53(12.9)$ & $13(7.1)$ & $40(17.6)$ & \\
\hline 4 & $20(4.9)$ & $2(1.1)$ & $18(7.9)$ & \\
\hline APACHE II score, median (IQR) & $17(12-26)$ & $13(9-18)$ & $23(16-30)$ & $<0.001$ \\
\hline APACHE II score $\geq 17, \mathrm{n}(\%)$ & $205(49.8)$ & $47(25.3)$ & $158(69.9)$ & $<0.001$ \\
\hline SOFA score, median (IQR) & $5(3-8)$ & $3(2-5)$ & $7(4-10)$ & $<0.001$ \\
\hline SOFA score $\geq 5, n(\%)$ & $199(51.0)$ & $51(29.0)$ & $148(69.2)$ & $<0.001$ \\
\hline Co-morbid diseases, n (\%) & $369(87.6)$ & $151(79.9)$ & $218(94)$ & $<0.001$ \\
\hline Hypertension & $216(51.3)$ & $80(42.3)$ & $136(58.6)$ & 0.001 \\
\hline Diabetes mellitus & $130(30.9)$ & $42(22.2)$ & $88(37.9)$ & $<0.001$ \\
\hline Cardiac disease & $106(25.2)$ & $31(16.4)$ & 75 (32.3) & $<0.001$ \\
\hline Respiratory disease & $82(19.5)$ & $36(19)$ & $46(19.8)$ & 0.84 \\
\hline Cancer & $45(10.7)$ & $14(7.4)$ & $31(13.4)$ & 0.049 \\
\hline Cerebrovascular disease & $37(8.8)$ & $7(3.7)$ & $30(12.9)$ & 0.001 \\
\hline Dementia & $26(6.2)$ & $9(4.8)$ & $17(7.3)$ & 0.27 \\
\hline End-stage renal disease & $15(3.6)$ & $2(1.1)$ & $13(5.6)$ & 0.01 \\
\hline
\end{tabular}

*ECOG score 0: Fully active, 1: Restricted in physically strenuous activity, 2: Ambulatory and capable of all selfcare; up and about more than $50 \%$ of waking hours, 3 : Capable of only limited selfcare; confined to bed or chair more than $50 \%$ of waking hours, 4 : Completely disabled; totally confined to bed or chair. 


\begin{tabular}{|c|c|c|c|c|}
\hline & $\begin{array}{l}\text { All patients } \\
n=421\end{array}$ & $\begin{array}{l}\text { 90-day } \\
\text { Survivors } \\
n=189\end{array}$ & $\begin{array}{l}\text { 90-day } \\
\text { Non- } \\
\text { survivors } \\
\mathrm{n}=232\end{array}$ & $\begin{array}{l}\mathrm{P} \\
\text { value }\end{array}$ \\
\hline Admission place, n (\%) & & & & 0.03 \\
\hline Ward & $247(59.4)$ & $125(66.1)$ & $122(53.7)$ & \\
\hline Emergency department & $119(28.6)$ & $43(22.8)$ & $76(33.5)$ & \\
\hline Other & $50(12.0)$ & $21(11.1)$ & $29(12.8)$ & \\
\hline \multicolumn{5}{|l|}{ Admission symptoms, $\mathrm{n}(\%)$} \\
\hline Shortness of breath & $268(63.7)$ & $114(60.3)$ & $154(66.4)$ & 0.20 \\
\hline Cough & $241(57.2)$ & $120(63.5)$ & $121(52.2)$ & 0.02 \\
\hline Fever & $232(55.1)$ & $122(64.6)$ & $110(47.4)$ & $<0.001$ \\
\hline Weakness & $126(29.9)$ & $57(30.2)$ & $69(29.7)$ & 0.93 \\
\hline Myalgia & $46(10.9)$ & $29(15.3)$ & $17(7.3)$ & $<0.01$ \\
\hline Diarrhea & $20(4.8)$ & $10(5.3)$ & $10(4.3)$ & 0.64 \\
\hline Chest pain & $19(4.5)$ & $7(3.7)$ & $12(5.2)$ & 0.47 \\
\hline Sore throat & $6(1.4)$ & $3(1.6)$ & $3(1.3)$ & 1.00 \\
\hline $\begin{array}{l}\text { Duration from symptom onset to hospital } \\
\text { admission, days, median (IQR) }\end{array}$ & $3(2-7)$ & $4(2-7)$ & $3(2-5)$ & 0.02 \\
\hline $\begin{array}{l}\text { Duration from symptom onset to ICU } \\
\text { admission, days, median (IQR) }\end{array}$ & $7(4-10)$ & $7(5-10)$ & $6(3-10)$ & $<0.01$ \\
\hline $\begin{array}{l}\text { Symptom onset to ICU admission of < } 7 \\
\text { days, } \mathrm{n}(\%)\end{array}$ & $192(49.6)$ & $79(43.4)$ & $113(55.1)$ & 0.02 \\
\hline $\mathrm{PaO}_{2} / \mathrm{FiO}_{2}, \mathrm{mmHg}$, median (IQR) & $\begin{array}{l}140(88- \\
205)\end{array}$ & $\begin{array}{l}170(110- \\
222)\end{array}$ & $\begin{array}{l}125(75- \\
188)\end{array}$ & $<0.001$ \\
\hline $\mathrm{PaO}_{2} / \mathrm{FiO}_{2} \leq 150 \mathrm{mmHg}, \mathrm{n}(\%)$ & $210(53.2)$ & $73(41.0)$ & $137(63.1)$ & $<0.001$ \\
\hline Lactate, $\mathrm{mmol} / \mathrm{L}$, median (IQR) & $1.4(1-2)$ & $\begin{array}{l}1.2(0.9- \\
1.6)\end{array}$ & $\begin{array}{l}1.6(1.1- \\
2.4)\end{array}$ & $<0.001$ \\
\hline Lactate $>2 \mathrm{mmol} / \mathrm{L}, \mathrm{n}(\%)$ & $98(24.4)$ & $18(10.3)$ & $80(35.4)$ & $<0.001$ \\
\hline
\end{tabular}

*ECOG score 0: Fully active, 1: Restricted in physically strenuous activity, 2: Ambulatory and capable of all selfcare; up and about more than $50 \%$ of waking hours, 3: Capable of only limited selfcare; confined to bed or chair more than $50 \%$ of waking hours, 4 : Completely disabled; totally confined to bed or chair. 


\begin{tabular}{|c|c|c|c|c|}
\hline & $\begin{array}{l}\text { All patients } \\
\mathrm{n}=421\end{array}$ & $\begin{array}{l}\text { 90-day } \\
\text { Survivors } \\
n=189\end{array}$ & $\begin{array}{l}\text { 90-day } \\
\text { Non- } \\
\text { survivors } \\
\mathrm{n}=232\end{array}$ & $\begin{array}{l}P \\
\text { value }\end{array}$ \\
\hline $\begin{array}{l}\text { Neutrophil / lymphocyte ratio, median } \\
\text { (IQR) }\end{array}$ & $\begin{array}{l}8.0(4.5- \\
13.1)\end{array}$ & $6.4(4.0-9.8)$ & $\begin{array}{l}9.8(5.7- \\
16.8)\end{array}$ & $<0.001$ \\
\hline Neutrophil / lymphocyte ratio $\geq 8, \mathrm{n}(\%)$ & $192(49.7)$ & $61(33.9)$ & $131(63.6)$ & $<0.001$ \\
\hline D-dimer, ng/mL, median (IQR) & $\begin{array}{l}1016(538- \\
2186)\end{array}$ & $\begin{array}{l}820(460- \\
1670)\end{array}$ & $\begin{array}{l}1200(600- \\
2850)\end{array}$ & $<0.01$ \\
\hline D-dimer > 1000 ng/mL, n (\%) & $123(50.6)$ & $49(43.0)$ & $74(57.4)$ & 0.02 \\
\hline
\end{tabular}

Treatment, complications and length of stay from admission till discharge in the survivor and nonsurvivor groups are seen in Table 2. At admission and during 10-day follow-up, conventional oxygen support was applied to $28.5 \%$ of the patients. HFNO and NIV were applied in $7.7 \%$ and $6.2 \%$ of patients, respectively, and $57.6 \%$ of the patients were intubated and mechanically ventilated. Hydroxychloroquine (88.6\%), favipiravir (82.7\%), antibiotics (82.7\%), azithromycin (56.8\%), oseltamivir (47.7\%) and corticosteroids (31.6\%) were the most frequently given medications to the patients. Mean fluid balance was $600(275-1000) \mathrm{ml} /$ per day and was higher in the non-survivor group $(\mathrm{p}<0.001)$. Common complications observed in patients during the follow-up were delirium $(9.7 \%)$ and cardiac arrhythmias (7.8\%). The median values of length of stay in ICU and hospital were 7 (3-14) and 15 (9-23) days, respectively. 
Table 2

Treatment, complications and length of stay from admission till discharge

\begin{tabular}{|c|c|c|c|c|}
\hline & $\begin{array}{l}\text { All patients } \\
n=421\end{array}$ & $\begin{array}{l}\text { 90-day } \\
\text { Survivors } \\
n=189\end{array}$ & $\begin{array}{l}90 \text {-day } \\
\text { Non- } \\
\text { survivors } \\
n=232\end{array}$ & $\begin{array}{l}P \\
\text { value }\end{array}$ \\
\hline Respiratory support, n (\%) & & & & $<0.001$ \\
\hline Conventional oxygen & $119(28.5)$ & $101(54.3)$ & $18(7.8)$ & \\
\hline High-flow nasal oxygen & $32(7.7)$ & $28(15.1)$ & $4(1.7)$ & \\
\hline Non-invasive ventilation & $26(6.2)$ & $16(8.6)$ & $10(4.3)$ & \\
\hline Invasive ventilation & $240(57.6)$ & $41(22.0)$ & $199(86.1)$ & \\
\hline \multicolumn{5}{|l|}{ Treatment, $\mathbf{n}(\%)$} \\
\hline Hydroxychloroquine & $373(88.6)$ & $168(88.9)$ & $205(88.4)$ & 0.86 \\
\hline Favipiravir & $348(82.7)$ & $156(82.5)$ & $192(82.8)$ & 0.95 \\
\hline Antibiotics & $348(82.7)$ & $145(76.7)$ & $203(87.5)$ & $<0.01$ \\
\hline Azithromycin & $239(56.8)$ & $112(59.3)$ & $127(54.7)$ & 0.35 \\
\hline Oseltamivir & $201(47.7)$ & $96(50.8)$ & $105(45.3)$ & 0.25 \\
\hline Corticosteroids & $133(31.6)$ & $55(29.1)$ & 78 (33.6) & 0.32 \\
\hline Vitamin C (more than RDA) & $131(31.1)$ & $52(27.5)$ & $79(34.1)$ & 0.14 \\
\hline Convalescent plasma & $53(12.6)$ & $23(12.2)$ & $30(12.9)$ & 0.81 \\
\hline Tocilizumab & $44(10.5)$ & $17(9.0)$ & $27(11.6)$ & 0.37 \\
\hline Zinc (more than RDA) & $35(8.3)$ & $17(9.0)$ & $18(7.8)$ & 0.64 \\
\hline Thiamine (more than RDA) & $31(7.4)$ & $15(7.9)$ & $16(6.9)$ & 0.68 \\
\hline Lopinavir/ritonavir & $21(5.0)$ & $8(4.2)$ & $13(5.6)$ & 0.52 \\
\hline Intravenous immunoglobulin & $10(2.4)$ & $4(2.1)$ & $6(2.6)$ & 1.00 \\
\hline Cytokine removal & $9(2.1)$ & $3(1.6)$ & $6(2.6)$ & 0.73 \\
\hline Plasmapheresis & $5(1.2)$ & $2(1.1)$ & $3(1.3)$ & 1.00 \\
\hline Neuromuscular blocker use, n (\%) & $98(23.5)$ & $17(9)$ & $81(35.4)$ & $<0.001$ \\
\hline Vasopressor therapy, n (\%) & $173(41.1)$ & $21(11.1)$ & $152(65.5)$ & $<0.001$ \\
\hline
\end{tabular}




\begin{tabular}{|c|c|c|c|c|}
\hline & $\begin{array}{l}\text { All patients } \\
n=421\end{array}$ & $\begin{array}{l}\text { 90-day } \\
\text { Survivors } \\
n=189\end{array}$ & $\begin{array}{l}\text { 90-day } \\
\text { Non- } \\
\text { survivors } \\
n=232\end{array}$ & $\begin{array}{l}P \\
\text { value }\end{array}$ \\
\hline $\begin{array}{l}\text { Mean fluid balance per day, median } \\
\text { (IQR) }\end{array}$ & $\begin{array}{l}600(275- \\
1000)\end{array}$ & $\begin{array}{l}393(167- \\
663)\end{array}$ & $\begin{array}{l}872(400- \\
1431)\end{array}$ & $<0.001$ \\
\hline $\begin{array}{l}\text { Mean fluid balance of } \geq 600 \text { per day, } \\
n(\%)\end{array}$ & $202(50.4)$ & $60(33.7)$ & $142(63.7)$ & $<0.001$ \\
\hline Acute kidney injury, n (\%) & $155(38.9)$ & $26(14.4)$ & $129(59.4)$ & $<0.001$ \\
\hline Delirium, n (\%) & $41(9.7)$ & $22(11.6)$ & $19(8.2)$ & 0.24 \\
\hline Cardiac arrhythmia, n (\%) & $33(7.8)$ & $3(1.6)$ & $30(12.9)$ & $<0.001$ \\
\hline Length of ICU stay, days, median (IQR) & $7(3-14)$ & $6(3-13)$ & $8(4-16)$ & 0.04 \\
\hline $\begin{array}{l}\text { Length of hospital stay, days, median } \\
\text { (IQR) }\end{array}$ & $15(9-23)$ & $\begin{array}{l}17(12.5- \\
25.5)\end{array}$ & $13(7-22)$ & $<0.001$ \\
\hline
\end{tabular}

As seen in Fig. 2 multivariate cox regression analysis revealed 8 variables relevant to 90 -day mortality as invasive mechanical ventilation (conventional oxygen as the reference), high lactate, age $\geq 60$ years, presence of cardiac arrhythmia, vasopressor therapy, mean fluid balance $\geq 600 \mathrm{ml} / \mathrm{day}, \mathrm{PaO}_{2} / \mathrm{FiO}_{2} \leq 150$ $\mathrm{mmHg}$, ECOG score $\geq 1$, adjusted for other variables (SOFA $\geq 5$; APACHE $I \geq 17$; presence of hypertension, diabetes mellitus, cardiac disease, cancer, cerebrovascular disease, end-stage renal disease; admission place; onset of symptoms to ICU admission < 7 days; neutrophil/lymphocyte ratio $\geq 8$; neuromuscular blocker use; development of acute kidney injury.

As seen in Fig. 3, Kaplan Meier survival analysis revealed significantly lower survival in patients who had received invasive mechanical ventilation compared to conventional $\mathrm{O}_{2}$, $\mathrm{HFNO}$ and NIV (Log-rank $\mathrm{p}$ value $<0.001)$.

\section{Discussion}

This study reporting the first pandemic wave results in Turkish intensive care units revealed 90-day mortality of $55.1 \%$. Invasive mechanical ventilation, high lactate level, age more than 60 years, development of cardiac arrhythmia, need for vasopressor treatment, positive fluid balance, severe hypoxemia $\left(\mathrm{PaO}_{2} / \mathrm{FiO}_{2} \leq 150\right)$ and not being fully active in performance status were determined to be the independent risk factors for 90-day mortality. 
There is only one study published so far that demonstrated the 90-day mortality rate and the risk factors for mortality in critically-ill patients with COVID-19 [19]. It was a multicenter, prospective, cohort study conducted in patients with laboratory-confirmed COVID-19 who were admitted to ICUs of 138 hospitals in France, Belgium, and Switzerland. In this study 90-day mortality was found to be $31 \%$ and older age, immunosuppression, severe obesity, diabetes mellitus, higher renal and cardiovascular SOFA score, lower $\mathrm{PaO}_{2} / \mathrm{FiO}_{2}$ ratio and shorter time between onset to first symptoms and $\mathrm{ICU}$ admission were found to be independent risk factors for 90-day mortality.

Mortality rates in critically-ill COVID-19 patients vary. In studies conducted in New York City, ICU and hospital mortality rates were found to be $39 \%$ and $60.4 \%$ respectively. $[12,23]$ In a multicenter, cohort study performed in 65 USA hospitals, the 28-day mortality was 35.4\% [24]. In another multicenter study conducted in Mexico, ICU mortality was determined as 51.8\% [18]. In the Italy-Lombardy region, ICU mortality was reported to be $48.7 \%$ and hospital mortality was $53.4 \%$ [13]. In another study conducted in England, Wales and Northern Ireland region, hospital mortality was found to be $42 \%$ [26]. ICU mortality was found to be $29 \%$ [27] in a study from Germany. In a retrospective study from China, 60-day mortality was reported as $61.5 \%$ [6]. These differences might be due to differences in disease severity, in surgecapacity, in resources, etc. Turkey has sufficient number of intensive care beds, reported to be more than 30 adult ICU beds per 100,000 population, around $30 \%$ of them located in private hospitals which had limited roles in the pandemic. However, there is severe shortage of intensive care workers, especially nurses in Turkey. In the OECD countries, number of physicians per 100,000 population is 348 and number of nurses per 100,000 population is 938 . In Turkey, these numbers are 348 and 301 , respectively. During the COVID-19 pandemic, surge-capacity were enhanced in many countries 28-30][24]. In a study conducted in Australia, the number of intensive care beds in the first wave of pandemic was increased by $191 \%$, the number of ventilators by $120 \%$, the number of senior doctors by $240 \%$ and the number of intensive care nurses by $249 \%$ [29]. However, in Turkey, even prior to COVID-19, number of patients per nurse could be as high as 4-5 in third level comprehensive units. Number of physiotherapists are even negligible.

As observed in our study, advanced age $[13,25]$ and accompanying comorbidities (hypertension, diabetes mellitus cardiovascular disease, etc.) [17] determine the short and long-term prognosis in patients with COVID-19.

Acute respiratory failure is the most common cause of intensive care admission in COVID-19 patients. $[19,26,27]$. Most of these patients require invasive mechanical ventilation. In studies, frequency of IMV varies between $12.2-88 \%[1,6,23,28]$. In our study, $52.4 \%$ of the patients had $\mathrm{PaO}_{2} / \mathrm{FiO}_{2}$ ratio below 150 and $57.6 \%$ of the patients needed IMV at admission or during the follow-up. In this study, both IMV and $\mathrm{PaO}_{2} / \mathrm{FiO}_{2} \leq 150$ were found to be risk factors determining 90-day mortality. In studies conducted in different parts of the world, mortality rates vary between $35.7-100 \%$ in invasively ventilated patients [14, $16,18]$. This variety among studies might be due to differences in standards of care, in surge-capacity, in resources and due to different treatment approaches in the first-wave[29]. 
In our study, the 90-day survival rate was found to be higher in patients who received HFNO, although patient numbers are few and HFNO or NIV failure rates have not been recorded in this study. With the COVID-19 pandemic, HFNO therapy has become widespread around the world [34]. One of the advantages of this treatment is that it can be used in wards as well as in the ICU. It has been shown that HFNO therapy reduced the need for IMV in COVID-19 patients with respiratory failure [35].

Blood lactate levels are used mostly to follow tissue perfusion in critically-ill patients [30]. Even minor increases in lactate levels are associated with higher mortality rates [31, 32]. In this study, non-survivors had higher lactate levels compared to survivors and lactate level $>2 \mathrm{mmol} / \mathrm{L}$ was an independent predictor of mortality. In COVID-19 patients, lactate levels were reported to be high in non-survivors [19, $23,27]$, however, in none of them it was determined to be a risk factor in multivariate analysis.

In this study, vasopressor treatment, which was given to $41.1 \%$ of the patients, was also an independent predictor of mortality. Although we have not recorded the underlying reasons for vasopressor use, this is a predictor of disease severity and to our knowledge there is no other study reporting vasopressor treatment as an independent risk factor for mortality, except REVA network study revealing cardiovascular SOFA score being an independent risk factor for mortality [19].

In this study, positive fluid balance was found to be an independent risk factor for 90-day mortality in ICU patients. It was well known that positive fluid balance increases morbidity and mortality in critically-ill patients with sepsis, septic shock and ARDS $[33,34]$. It had also been shown that negative fluid balance reduces the need for renal replacement therapy and respiratory failure in critically-ill patients [35, 36]. To our knowledge, this is the first study reporting positive fluid balance as an independent predictor of mortality. This finding necessitates meticulous control of fluid balance in critically-ill COVID-19 patients.

The ECOG scoring system is used to evaluate the physical performance of patients in chronic diseases such as cancer [34]. In this study, we preferred to use ECOG score as it is easy to use and is widely known. Patients who were not fully active had poor prognosis. To our knowledge, this factor was not evaluated in other studies. However, in REVA network-COVID-ICU study, clinical frailty scale (CFS) was found to be higher in patients who died within 90 days [19], as was the VIP1 study where CFS was found to be related with 30-day mortality in critically-ill very elderly patients [37].

In studies, cardiac damage / arrhythmia was common in COVID-19 patients and it was related with increased mortality $[25,26,38-40]$. We observed cardiac arrhythmia in $33(7.8 \%)$ patients, and this was a risk factor that increased 90 -day mortality similar to other studies. This may be due to medications and/or due to the disease itself. In the early days of the COVID-19 pandemic, hydroxychloroquine alone or together with azithromycin was used frequently in some parts of the world $[23,25,41]$ and in our country [2], as well. In this study, hydroxychloroquine had been given to $86 \%$ and azithromycin to $56.8 \%$ patients.

The major strength of this study is that it has been conducted as a multicenter study in Turkish ICUs. As the pandemic is a major threat globally, data from various countries and geographic regions with different income levels and resources are needed. In addition, there are few studies reporting long term 
mortality rates in COVID-19 patients, to our knowledge, this one being the second one reporting 90-day mortality. We even need longer term outcome. And, finally some new independent predictors of mortality such as positive fluid balance, baseline performance status, high admission lactate and vasopressor use have been determined which need to be validated in future studies.

However, this study has several limitations. Number of ICUs and patients are limited due to the short study duration, and although ICUs entering the study are from different regions of Turkey, the results might not reflect the whole country. The study was conducted during the first wave and might not reflect the current situation. In addition, there might be other factors influencing mortality, which could not have been included in the study due to its design.

\section{Conclusion}

In this multicenter cohort study of critically-ill adult patients with COVID-19 in Turkey, more than half of patients died within 90 days after ICU admission. Receiving invasive mechanical ventilation, lactate level $>2 \mathrm{mmol} / \mathrm{L}$, age $\geq 60$ years, having cardiac arrhythmia during ICU stay, receiving vasopressor treatment during ICU stay, positive fluid balance of $\geq 600 \mathrm{ml}$ per day during ICU follow-up, admission $\mathrm{PaO}_{2} / \mathrm{FiO}_{2}$ ratio of $\leq 150 \mathrm{mmHg}$, and baseline ECOG score $\geq 1$ have been found to be independent risk factors for 90-day mortality.

\section{Declarations}

\section{Acknowledgement}

We thank to Omega CRO and all dedicated health care workers caring for COVID-19 patients.

The preliminary results of this study was presented in ESICM LIVES 2020 as an e-poster.

\section{Authors contributions}

KG, IHA, PH, BH, ST and AT: Conception, design of the work and the acquisition, analysis.KG, IHA, PH, BH, ST, ZG, KI, YB, FTB, FY, MS, RCY, EE, NDA, LT, GE, GG, IK, EA, SY, TM, SS, TA, BAC, AAA,DAO, TKS, AUE, AF, FA, MCG, AZ, AG, MT, MA, RU, JBC, CB, CK, EK, EO, EOE, SO, IAS, IHT, BC, BE, KTS, JE, UGY, NT, MS, AT: Interpretation of data, the creation of new software used in the work, have drafted the work or substantively revised. All authors read and approved the final manuscript.

\section{Funding}

None

\section{Availability of data and materials}


After publication, data are available upon reasonable request. A proposal with a detailed description of study objectives and statistical analysis plan will be needed for evaluation of the reasonability of requests. Additional materials might also be required during the process of evaluation.

Ethics approval and consent to participate

The case series was approved by Ethics Committee of Erciyes University (Date: 22.07.2020 no:2020/401). Written informed consent was waived.

\section{Consent for publication}

Written informed consent for publication was obtained from all authors.

\section{Competing interests}

All the authors state that there are no conflict of interest related to this study.

\section{References}

1. Richardson S, Hirsch JS, Narasimhan M, Crawford JM, McGinn T, Davidson KW, Barnaby DP, Becker LB, Chelico JD, Cohen SL et al: Presenting Characteristics, Comorbidities, and Outcomes Among 5700 Patients Hospitalized With COVID-19 in the New York City Area. Jama 2020, 323(20):20522059.

2. Sahin Temel KG, Birkan Ulger, Huseyin Arican, Kadir Bulut, Ali Sari, Hilal Sipahioglu, Ali Yesiltepe, Aysim Erturk, Ozgur Karabiyik, Murat Sungur: Characteristics and outcomes of patients infected with SARS-CoV-2 admitted to intensive care units: Erciyes University covid-19 center experience. Erciyes Med J 2020.

3. Guan WJ, Ni ZY, Hu Y, Liang WH, Ou CQ, He JX, Liu L, Shan H, Lei CL, Hui DSC et al: Clinical Characteristics of Coronavirus Disease 2019 in China. The New England journal of medicine 2020, 382(18):1708-1720.

4. Wu C, Chen X, Cai Y, Xia J, Zhou X, Xu S, Huang H, Zhang L, Zhou X, Du C et al: Risk Factors Associated With Acute Respiratory Distress Syndrome and Death in Patients With Coronavirus Disease 2019 Pneumonia in Wuhan, China. JAMA internal medicine 2020, 180(7):934-943.

5. Halacli B, Kaya A, Topeli A: Critically-ill COVID-19 patient. Turkish journal of medical sciences 2020, 50(Si-1):585-591.

6. Xu J, Yang X, Yang L, Zou X, Wang Y, Wu Y, Zhou T, Yuan Y, Qi H, Fu S et al: Clinical course and predictors of 60-day mortality in 239 critically ill patients with COVID-19: a multicenter retrospective study from Wuhan, China. Critical care (London, England) 2020, 24(1):394.

7. Fox SE, Akmatbekov A, Harbert JL, Li G, Quincy Brown J, Vander Heide RS: Pulmonary and cardiac pathology in African American patients with COVID-19: an autopsy series from New Orleans. The Lancet Respiratory medicine 2020, 8(7):681-686. 
8. Gündoğan K TŞ, Baran Ketencioğlu B, Rabah B, Tutar N, Sungur M: Acute Kidney Injury in SARS-CoV2 Infected Critically III Patients. Turk J Nephrol 2020, 3(29):185-189.

9. Tutar N, Baran Ketencioglu B, Temel Ş, Gündoğan K, Karabıyık Ö, Sungur M: Images in Vascular Medicine: Peripheral artery thrombosis in critically ill patients with COVID-19. Vascular medicine (London, England) 2020:1358863×20938431.

10. Lax SF, Skok K, Zechner P, Kessler HH, Kaufmann N, Koelblinger C, Vander K, Bargfrieder U, Trauner M: Pulmonary Arterial Thrombosis in COVID-19 With Fatal Outcome : Results From a Prospective, Single-Center, Clinicopathologic Case Series. Annals of internal medicine 2020, 173(5):350-361.

11. Verdoni L, Mazza A, Gervasoni A, Martelli L, Ruggeri M, Ciuffreda M, Bonanomi E, D'Antiga L: An outbreak of severe Kawasaki-like disease at the Italian epicentre of the SARS-CoV-2 epidemic: an observational cohort study. Lancet (London, England) 2020, 395(10239):1771-1778.

12. Petrilli CM, Jones SA, Yang J, Rajagopalan H, O'Donnell L, Chernyak Y, Tobin KA, Cerfolio RJ, Francois F, Horwitz LI: Factors associated with hospital admission and critical illness among $\mathbf{5 2 7 9}$ people with coronavirus disease 2019 in New York City: prospective cohort study. BMJ (Clinical research ed) 2020, 369:m1966.

13. Grasselli G, Greco M, Zanella A, Albano G, Antonelli M, Bellani G, Bonanomi E, Cabrini L, Carlesso E, Castelli $\mathrm{G}$ et al: Risk Factors Associated With Mortality Among Patients With COVID-19 in Intensive Care Units in Lombardy, Italy. JAMA internal medicine 2020.

14. Karagiannidis C, Mostert C, Hentschker C, Voshaar T, Malzahn J, Schillinger G, Klauber J, Janssens U, Marx G, Weber-Carstens S et al: Case characteristics, resource use, and outcomes of 10021 patients with COVID-19 admitted to 920 German hospitals: an observational study. The Lancet Respiratory medicine 2020, 8(9):853-862.

15. Xie J, Wu W, Li S, Hu Y, Hu M, Li J, Yang Y, Huang T, Zheng K, Wang Y et al: Clinical characteristics and outcomes of critically ill patients with novel coronavirus infectious disease (COVID-19) in China: a retrospective multicenter study. Intensive care medicine 2020:1-10.

16. Auld SC, Caridi-Scheible M, Blum JM, Robichaux C, Kraft C, Jacob JT, Jabaley CS, Carpenter D, Kaplow R, Hernandez-Romieu AC et al: ICU and Ventilator Mortality Among Critically III Adults With Coronavirus Disease 2019. Critical care medicine 2020, 48(9):e799-e804.

17. Zhou F, Yu T, Du R, Fan G, Liu Y, Liu Z, Xiang J, Wang Y, Song B, Gu X et al: Clinical course and risk factors for mortality of adult inpatients with COVID-19 in Wuhan, China: a retrospective cohort study. Lancet (London, England) 2020, 395(10229):1054-1062.

18. Ñamendys-Silva SA, Alvarado-Ávila PE, Domínguez-Cherit G, Rivero-Sigarroa E, Sánchez-Hurtado LA, Gutiérrez-Villaseñor A, Romero-González JP, Rodríguez-Bautista H, García-Briones A, GarnicaCamacho CE et al: Outcomes of patients with COVID-19 in the intensive care unit in Mexico: A multicenter observational study. Heart \& lung : the journal of critical care 2021, 50(1):28-32.

19. Clinical characteristics and day-90 outcomes of 4244 critically ill adults with COVID-19: a prospective cohort study. Intensive care medicine 2020:1-14.

20. TEAM W: Clinical management of COVID-19. 2020:1-62. 
21. Simpson S, Kay FU, Abbara S, Bhalla S, Chung JH, Chung M, Henry TS, Kanne JP, Kligerman S, Ko JP et al: Radiological Society of North America Expert Consensus Statement on Reporting Chest CT Findings Related to COVID-19. Endorsed by the Society of Thoracic Radiology, the American College of Radiology, and RSNA - Secondary Publication. Journal of thoracic imaging 2020, 35(4):219-227.

22. Khwaja A: KDIGO clinical practice guidelines for acute kidney injury. Nephron Clinical practice 2012, 120(4):c179-184.

23. Cummings MJ, Baldwin MR, Abrams D, Jacobson SD, Meyer BJ, Balough EM, Aaron JG, Claassen J, Rabbani LE, Hastie $\mathrm{J}$ et al: Epidemiology, clinical course, and outcomes of critically ill adults with COVID-19 in New York City: a prospective cohort study. Lancet (London, England) 2020, 395(10239):1763-1770.

24. Salluh JIF, Lisboa T, Bozza FA: Challenges for the care delivery for critically ill COVID-19 patients in developing countries: the Brazilian perspective. Critical care (London, England) 2020, 24(1):593.

25. Gupta S, Hayek SS, Wang W, Chan L, Mathews KS, Melamed ML, Brenner SK, Leonberg-Yoo A, Schenck EJ, Radbel J et al: Factors Associated With Death in Critically III Patients With Coronavirus Disease 2019 in the US. JAMA internal medicine 2020, 180(11):1-12.

26. Du RH, Liang LR, Yang CQ, Wang W, Cao TZ, Li M, Guo GY, Du J, Zheng CL, Zhu Q et al: Predictors of mortality for patients with COVID-19 pneumonia caused by SARS-CoV-2: a prospective cohort study. The European respiratory journal 2020, 55(5).

27. Yang X, Yu Y, Xu J, Shu H, Xia J, Liu H, Wu Y, Zhang L, Yu Z, Fang M et al: Clinical course and outcomes of critically ill patients with SARS-CoV-2 pneumonia in Wuhan, China: a single-centered, retrospective, observational study. The Lancet Respiratory medicine 2020, 8(5):475-481.

28. Grasselli G, Zangrillo A, Zanella A, Antonelli M, Cabrini L, Castelli A, Cereda D, Coluccello A, Foti G, Fumagalli R et al: Baseline Characteristics and Outcomes of 1591 Patients Infected With SARS-CoV2 Admitted to ICUs of the Lombardy Region, Italy. Jama 2020.

29. Azoulay E, de Waele J, Ferrer R, Staudinger T, Borkowska M, Povoa P, lliopoulou K, Artigas A, Schaller SJ, Shankar-Hari M et al: International variation in the management of severe COVID-19 patients. Critical care (London, England) 2020, 24(1):486.

30. Vincent JL, De Backer D: Circulatory shock. The New England journal of medicine 2013, 369(18):1726-1734.

31. Singer M, Deutschman CS, Seymour CW, Shankar-Hari M, Annane D, Bauer M, Bellomo R, Bernard GR, Chiche JD, Coopersmith CM et al: The Third International Consensus Definitions for Sepsis and Septic Shock (Sepsis-3). Jama 2016, 315(8):801-810.

32. Nichol AD, Egi M, Pettila V, Bellomo R, French C, Hart G, Davies A, Stachowski E, Reade MC, Bailey M et al: Relative hyperlactatemia and hospital mortality in critically ill patients: a retrospective multicentre study. Critical care (London, England) 2010, 14(1):R25.

33. van Mourik N, Geerts BF, Binnekade JM, Veelo DP, Bos LDJ, Wiersinga WJ, van der Poll T, Cremer OL, Schultz MJ, Vlaar APJ: A Higher Fluid Balance in the Days After Septic Shock Reversal Is Associated 
With Increased Mortality: An Observational Cohort Study. Critical care explorations 2020, 2(10): $\mathrm{e} 0219$.

34. de Oliveira FS, Freitas FG, Ferreira EM, de Castro I, Bafi AT, de Azevedo LC, Machado FR: Positive fluid balance as a prognostic factor for mortality and acute kidney injury in severe sepsis and septic shock. Journal of critical care 2015, 30(1):97-101.

35. Douglas IS, Alapat PM, Corl KA, Exline MC, Forni LG, Holder AL, Kaufman DA, Khan A, Levy MM, Martin GS et al: Fluid Response Evaluation in Sepsis Hypotension and Shock: A Randomized Clinical Trial. Chest 2020, 158(4):1431-1445.

36. Wang YM, Zheng YJ, Chen Y, Huang YC, Chen WW, Ji R, Xu LL, Yang ZT, Sheng HQ, Qu HP et al: Effects of fluid balance on prognosis of acute respiratory distress syndrome patients secondary to sepsis. World journal of emergency medicine 2020, 11(4):216-222.

37. Flaatten H, De Lange DW, Morandi A, Andersen FH, Artigas A, Bertolini G, Boumendil A, Cecconi M, Christensen $S$, Faraldi $L$ et al: The impact of frailty on ICU and 30-day mortality and the level of care in very elderly patients ( $\geq 80$ years). Intensive care medicine 2017, 43(12):1820-1828.

38. Shi S, Qin M, Shen B, Cai Y, Liu T, Yang F, Gong W, Liu X, Liang J, Zhao Q et al: Association of Cardiac Injury With Mortality in Hospitalized Patients With COVID-19 in Wuhan, China. JAMA cardiology 2020, 5(7):802-810.

39. Yu Y, Xu D, Fu S, Zhang J, Yang $X, X u L$, Xu J, Wu Y, Huang C, Ouyang $Y$ et al: Patients with COVID-19 in 19 ICUs in Wuhan, China: a cross-sectional study. Critical care (London, England) 2020, 24(1):219.

40. Liao SC, Shao SC, Cheng CW, Chen YC, Hung MJ: Incidence rate and clinical impacts of arrhythmia following COVID-19: a systematic review and meta-analysis of 17,435 patients. Critical care (London, England) 2020, 24(1):690.

41. Horby P, Mafham M, Linsell L, Bell JL, Staplin N, Emberson JR, Wiselka M, Ustianowski A, Elmahi E, Prudon B et al: Effect of Hydroxychloroquine in Hospitalized Patients with Covid-19. The New England journal of medicine 2020, 383(21):2030-2040.

\section{Figures}




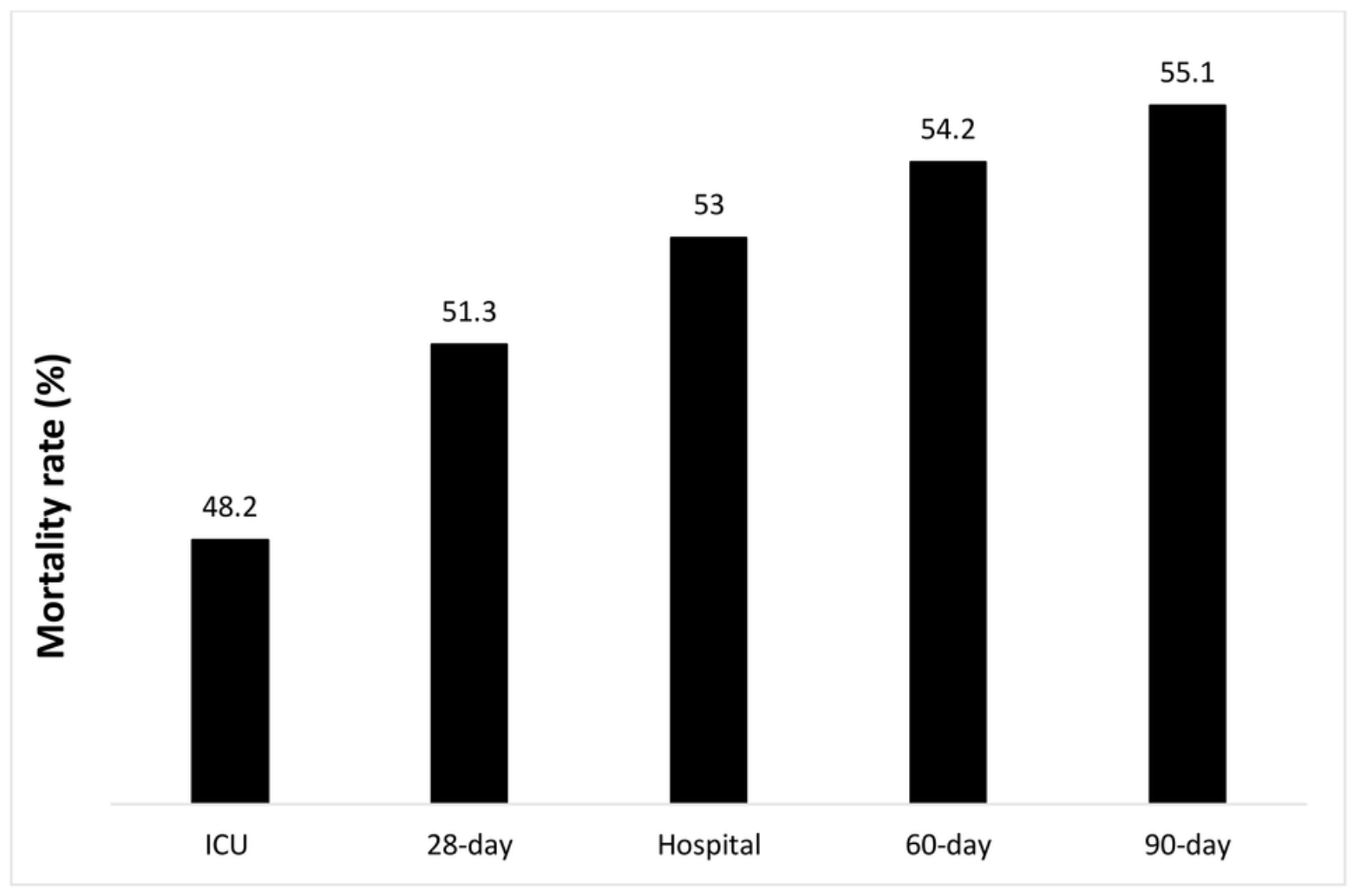

Figure 1

ICU, 28-day, hospital, 60-day and 90-day mortality rates. 


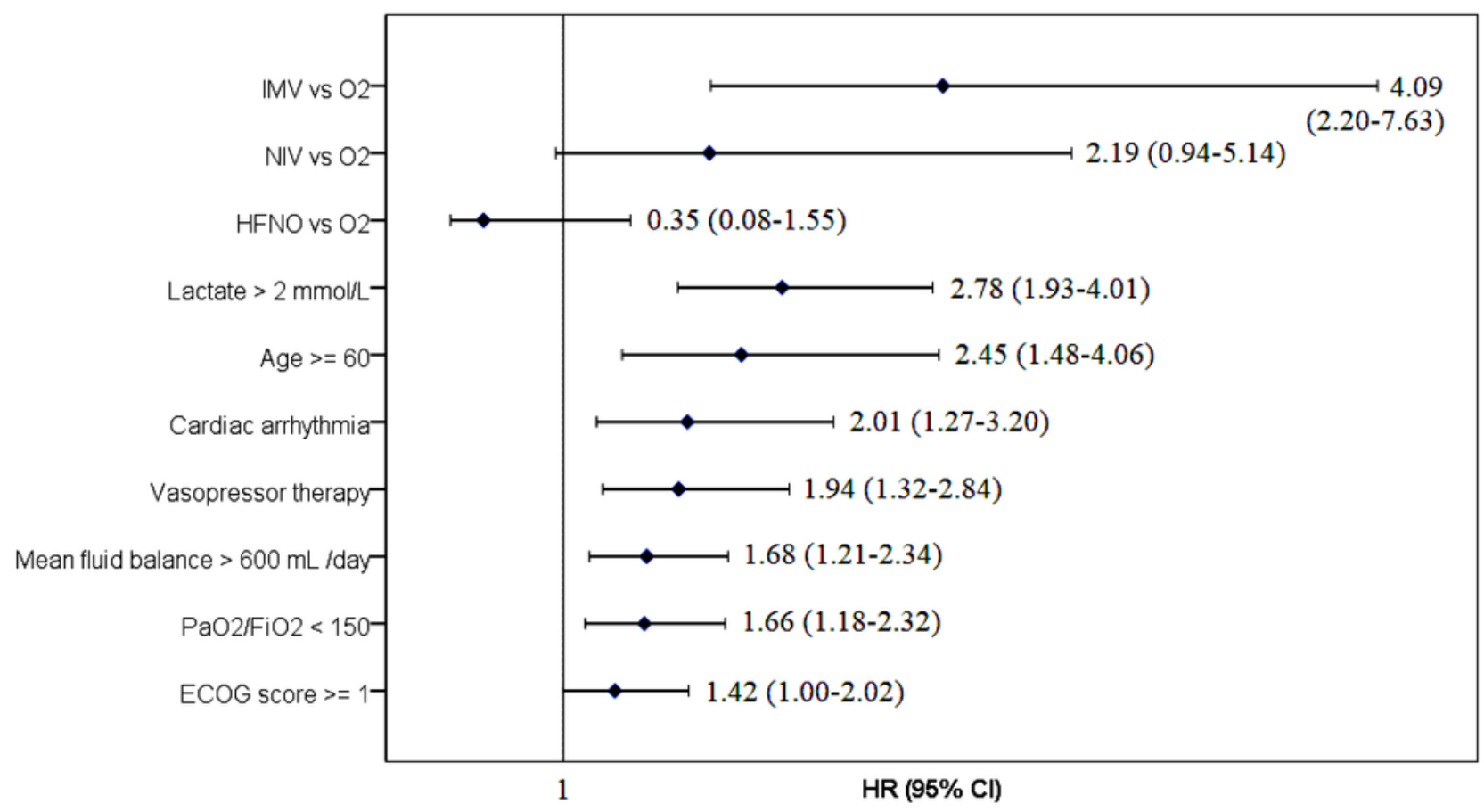

Figure 2

Multivariate Cox Proportional Hazard Regression Analysis of factors associated with 90-day mortality as a forrest plot graph. IMV: Invasive mechanical ventilation, O2: Oxygen, NIV: Non-invasive mechanical ventilation, HFNO: High-flow nasal oxygen, PaO2: Partial arterial oxygen pressure FiO2: Fraction of inspired oxygen, ECOG: Eastern Cooperative Oncology Group Performance Status, HR: Hazard ratio, Cl: Confidence interval. 


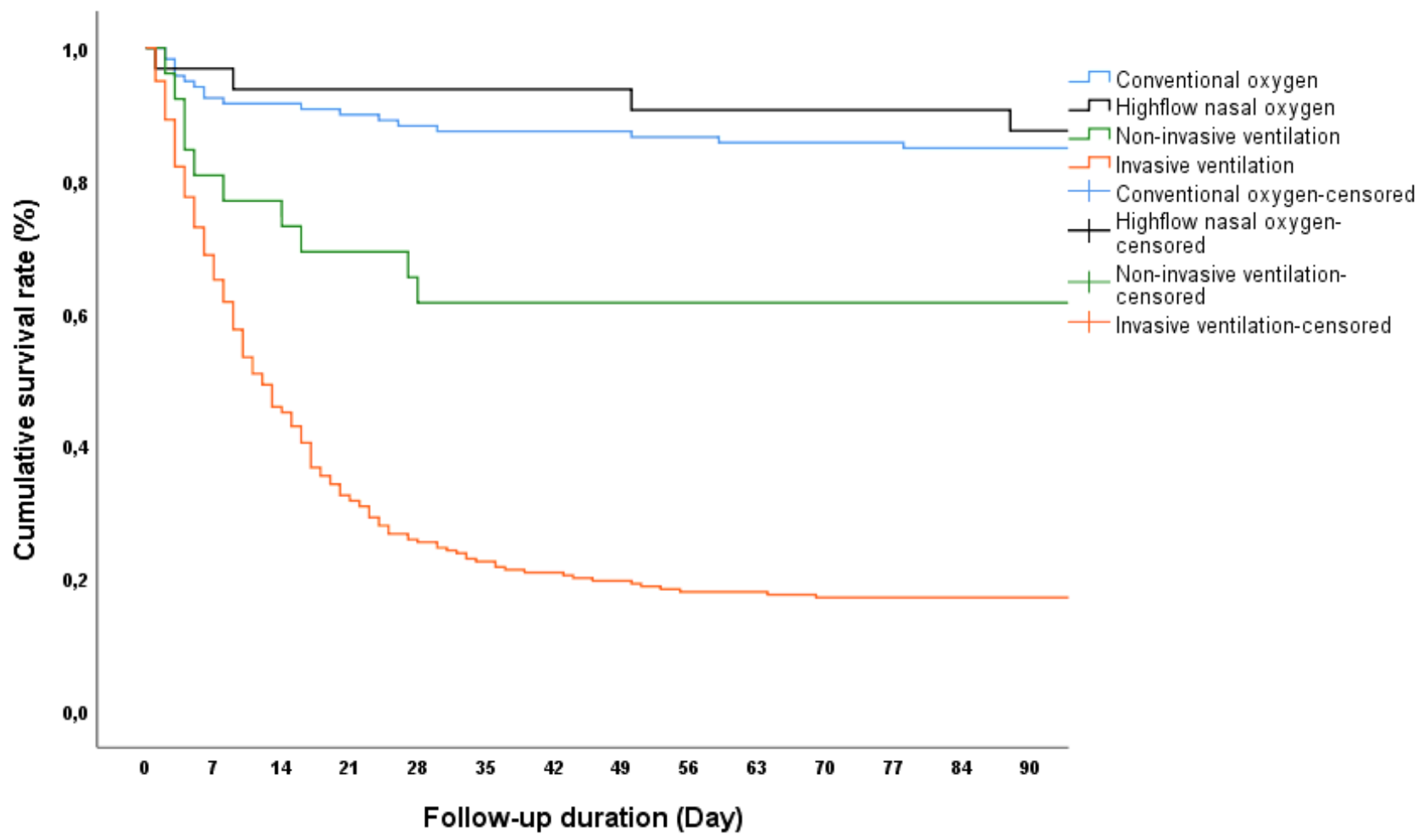

No.at risk

$\begin{array}{ccccccccccccccc}- & 119 & 110 & 109 & 107 & 105 & 104 & 104 & 104 & 103 & 102 & 102 & 102 & 101 & 101 \\ - & 32 & 31 & 30 & 30 & 30 & 30 & 30 & 30 & 29 & 29 & 29 & 29 & 29 & 28 \\ & 26 & 21 & 20 & 18 & 17 & 16 & 16 & 16 & 16 & 16 & 16 & 16 & 16 & 16 \\ & 240 & 165 & 110 & 78 & 62 & 54 & 50 & 47 & 43 & 43 & 41 & 41 & 41 & 41\end{array}$

Figure 3

Kaplan-Meier survival curves for 90-day mortality according to respiratory support. Log-rank test $\mathrm{p}<$ 0.001 .

\section{Supplementary Files}

This is a list of supplementary files associated with this preprint. Click to download.

- FigureS1.pdf

- Figures2.tif

- Tables1.pdf 